\title{
The effect of usnic acid supplementation on rabbit's tissues surrounding implant apoptosis and some enzyme activities
}

Fehmi Odabasoglu' ${ }^{*}$, Omer S Yildirim ${ }^{2}$, Zekai Halici ${ }^{3}$, Hayati Aygun ${ }^{4}$, Mesut Halici ${ }^{5}$, Fadime Atalay ${ }^{1}$, Elif Cadirci ${ }^{6}$, Ismail Can ${ }^{7}$, Ahmet $^{2}$ Cakir $^{8}$, Ozlem Aydin Berktas ${ }^{9}$, Ali Aslan ${ }^{10,14}$, Yasin Bayir ${ }^{11}$, Fazli Erdogan ${ }^{12}$ and Bunyamin Aksakal ${ }^{13}$

${ }^{1}$ Faculty of Medicine, Department of Medical Biochemistry, Kafkas University, Kars, Turkey

${ }^{2}$ Faculty of Medicine, Department of Orthopaedics and Traumatology, Ataturk University, Erzurum, Turkey

${ }^{3}$ Faculty of Medicine, Department of Pharmacology, Ataturk University, Erzurum, Turkey

${ }^{4}$ Medicine Faculty, Department of Orthopaedics and Traumatology, Uludağ University, Bursa, Turkey

${ }^{5}$ Faculty of Veterinary, Department of Biochemistry, Ataturk University, Erzurum, Turkey

${ }^{6}$ Faculty of Phar11macy, Department of Pharmacology, Ataturk University, Erzurum, Turkey

${ }^{7}$ Faculty of Medicine, Department of Histology-Embryology, Kafkas University, Kars, Turkey

${ }^{8}$ Faculty of Science, Department of Chemistry, Kilis 7 Aralık University, Kilis, Turkey

${ }^{9}$ Faculty of Healthy Science, Department of Nursing, Giresun University, Giresun, Turkey

${ }^{10}$ Faculty of Pharmacy, Department of Botany, Yuzuncu Yil University, Van, Turkey

${ }^{11}$ Faculty of Pharmacy, Department of Biochemistry, Ataturk University, Erzurum, Turkey

${ }^{12}$ Surgical Sciences, Department of Pathology, Yildirim Beyazit University, Ankara, Turkey

${ }^{13}$ Department of Metallurgy and Materials Engineering, Yildiz Technical University, Istanbul, Turkey

${ }^{14}$ Faculty of Arts and Science, Department of Biology, Kyrgyz-Turkish Manas University, Bishkek, Kyrgyzstan

\begin{abstract}
Usnea longissima Ach., is a type of lichen known for its protective effects. In this study, we examined the effects of olive oil and usnic acid against apoptosis in rabbit femurs after titanium implantation. We determined that lichen metabolite and olive oil activate caspase-dependent programmatic cell death unlike necrosis. Both orally and locally administered olive oil and usnic acid showed proapoptotic effect through the activation of caspase 2,3 , 8 and 9 . Also, they showed strong myeloperoxidase (MPO) and inducible nitric oxide synthase (iNOS) activities. However, iNOS and MPO activities do not have a strong effect in local application. Furthermore, usnic acid and olive oil decreased SOD activity and GSH level. In parallel, titanium implantation in these tissues also decreased. In the light of the data obtained, both usnic acid and olive oil induced apoptotic cell death. Therefore, it can be used as a proapoptotic agent in the treatment of various diseases.
\end{abstract}

\section{Introduction}

Titanium, commonly used in medical devices due to its unique physiochemical and biological properties, conventionally take a part in joint replacements, dental implants, spinal fixation devices and cardiovascular stents equipments [1]. Because of corrosion resistance feature, it can be used as clinical implant material.

Titanium behave as a foreign body response among the inflammation. During the formation of inflammation cells, it exhibits a normal recovery. In addition to this, titanium particles cells also stimulate apoptosis [2].

Apoptosis plays an important role not only growing up of multi cellular organism and hemostasis, but also prostheses localization. Cell number is regulated via three ways which are during the morphogenesis process in embryo, tissue turnover in mature and after the immune response. Because of that reason, many diseases are related with apoptosis [3]. Because of that reason, many diseases are related with apoptosis. Membrane receptors are basically responsible for the physiological process of apoptosis. In order to initiate signal complex that induce the apoptosis process, activated receptors signal to procaspase and adapter proteins. Caspases are cytosolic enzymes which exist in mammalians as a hidden form and require activation to be functional. Caspases are classified into three groups which are initiater, killer and stokin processor. Initiators are activated by censors of cell death pathway and initiate the caspase cascade. The structural proteins and necessary enzymes for homeostasis is broken by executive caspase [4].

The ethology of tissue degeneration is still unknown. therefore, ethology of tissue damage of reactive oxygen species is a common field of study [5]. Normally, reactive oxygen species are generated in low concentration and their control is managed by antioxidant mechanisms. Excess production or low excretion of ROS causes serious metabolic abnormalities and oxidative stress that damage on biological macro molecules [6].

${ }^{\star}$ Correspondence to: Fehmi Odabasoglu, Faculty of Medicine, Dep. of Medical Biochemistry, Kafkas University, Kars, Turkey, E-mail: fodabasoglu@gmail.com Key words: Usnic acid, titanium alloy, apoptosis, caspases, antioxidant, olive oil Received: May 16, 2019; Accepted: June 14, 2019; Published: June 21, 2019 
Lichens, symbiotic organisms, have common usage due to its therapeutic features in several diseases which contains both algae and fungal [7]. Usnea longisima whose antioxidant and anti-ulcer activities was studied by our research group was investigated in treatment of broken bone, leg lesions and wards [8]. Among the lichen metabolites, the most common is usnic acid. The different activities have been determined in many studies. However, there were no studies on proapoptotic activity [9-13].

In addition to this, there is no report about apoptosis feature of this lichen in literature. At the same time, it is reported that olive oil, a very important part of mediterranean diet, have protective effect on several diseases such as autoimmune, chronic and acute inflammatory and diseases [14]. The effect of usnic acid whose proapoptotic effect is exhibited by Odabasoglu et all, along with olive oil is not reported up to now [15]. This study was designed to evaluate the effects some apoptotic parameters and some biochemical parameters in the tissues surrounding the implant in Ti-implanted rabbits.

\section{Materials and methods}

\section{Plant material}

It is collected from the Giresun region (northern Anatolia) of Turkey. U. longissima identified by Dr. Ali Aslan and has been stored in the herbarium of Kazim Karabekir Education Faculty, Ataturk University, Erzurum (Turkey).

\section{General analytical procedures}

The chemicals used in experiments were received Sigma Chemicals. The cell death detection kits were bought from Roche Applied Science (Penzberg, Germany). The olive oil obtained a retail market (Ulker A.S.-Bizim, Turkey). Colon chromatography (CC) was performed on silica gel 60 (70-230 mesh) and thin layer chromatography (TLC) was carried out on silica gel 60F254-coated aluminium plates (Merck).

The spots on the TLC were visualized at ultraviolet (UV) $254 \mathrm{~nm}$. Infra-red (IR) spectra were recorded with $\mathrm{KBr}$ pellets on a Shimadzu FT-IR 8000 spectrophotometer. Nuclear Magnetic Resonance (NMR) spectra were obtained with the Varian spectrometer at $400 \mathrm{MHz}$ for $1 \mathrm{H}$ and $100 \mathrm{MHz}$ for $13 \mathrm{C}(\delta)$. Tetramethylsilane (TMS) was used as an internal standard. UV-visible spectra of usnic acid and biochemical assays were recorded on a Thermo Spectronic-HE $\lambda$ IOS $\beta$ spectrophotometer. Melting points were determined on a Buchi 510 melting point apparatus and are uncorrected.

\section{Extraction of lichen sample and isolation of usnic acid (UA)}

Usnea longissima (100 g) was extracted with $150 \mathrm{ml}$ of diethyl ether. The obtained extract stored at $4{ }^{\circ} \mathrm{C}$ for $24 \mathrm{~h}$ to precipitate UA. After the UA precipitates were subjected to column chromatography, material of $840 \mathrm{mg}$ was obtained. The structure of the usnic acid was elucidated by UV, IR, 1 H NMR and 13 C NMR methods [16].

\section{Animals}

The 18 New Zealand rabbits, weighing 3600-4000 gr, were kept on the same conditions before the experiment [17].

\section{Implants}

Ti6Al4V implant discs were cut into cylinders. The bars were produced a diameter of $10 \mathrm{~mm}$ and a thickness of $1 \mathrm{~mm}$. They were sterilized.

\section{Titanium implantation in rabbits}

The rabbits were divided into six different groups; - the healthy group

- only Ti-implanted group

- Ti-implanted and orally administered olive oil group

- Ti-implanted and locally administered olive oil plus usnic acid group

- Ti-implanted and orally administered olive oil plus usnic acid group

The Ti6Al4V implants were placed in the rabbit's legs. The olive oil and usnic acid were given once every 3 days for the next 21 days. Other groups served as a healthy control. After administration, the animals were sacrificed with $100 \mathrm{mg} / \mathrm{kg}$ thiopental sodium. The tissues surrounding the implant were carefully removed with a trephine. Some of the removed tissues were washed with physiological water and stored at $-80^{\circ} \mathrm{C}$ for biochemical analyses. While the other tissues contained in $\% 10$ formalin for histopathology.

\section{Quantification of apoptosis in tissues surrounding the implants}

A TUNEL assay was done the Ti-implanted rabbit femurs. The In Situ Cell Death Detection Kit (Roche Applied Science, Penzberg, Germany) was used to to quantify the relative number of cells. The apoptotic cells counted in light microscope (Olympus BH-40). The results were expressed as the apoptotic index, which was defined as the number of (TUNEL-positive cells /cell number count) $\times 100$.

\section{Biochemical investigation of tissues}

SOD, iNOS, MPO, CAS 2, CAS 3, CAS 8, and CAS 9 enzymes activities and the amounts of GSH were detected in tissues waiting at $-80^{\circ} \mathrm{C}$. The measurements were made according to the literature.

\section{Superoxide dismutase (SOD) activity}

SOD activity was measured in accordance with Sun et al. (1988) [18]. In the presence of SOD, produces superoxide radical by xanthine and xanthine oxidase. The formed compound forms a formazan dye with NTB. The activity of the resulting compound is measured at 560 $\mathrm{nm}$ and is expressed as millimol per minute per milligram of tissue ( $\mathrm{mmol} / \mathrm{min} / \mathrm{mg}$ tissue).

\section{Total glutathione (GSH) determination}

The amount of GSH in the tissues was measured according to the method described by Sedlak and Lindsay (1968) with slight modifications [19].

The rat stomach tissues weighed. They were homogenized in $2 \mathrm{ml}$ of $50 \mathrm{mM}$ Tris- $\mathrm{HCl}$ buffer containing $20 \mathrm{mM}$ ethylenediaminetetraacetic acid (EDTA). The homogenate was centrifuged at $4200 \mathrm{rpm}$ for 40 $\min$ at $4{ }^{\circ} \mathrm{C}$. The amount of GSH was determined using 5,5'-dithiobis(2-nitrobenzoic acid) (DTNB) in the supernatant. Absorbance was measured at $412 \mathrm{~nm}$. The results of the GSH level in tissues around the implants were expressed as nanomoles per milligram of tissue (nmol/ mg tissue).

\section{Myeloperoxidase (MPO) activity}

MPO activity was measured according to the modified method of Bradley et al. (1982) [20]. The homogenates were centrifuged at 1500 $\mathrm{g}$ for $10 \mathrm{~min}$ at $4{ }^{\circ} \mathrm{C}$. MPO activity was determined by adding $100 \mu \mathrm{l}$ supernatant to $1.9 \mathrm{ml}$ of $10 \mathrm{mmol} / \mathrm{l}$ phosphate buffers ( $\mathrm{pH} \mathrm{6.0)}$ and 1 
$\mathrm{ml}$ of $1.5 \mathrm{~mol} / \mathrm{l}$ o-dianisidine hydrochloride containing $0.0005 \% \mathrm{w} / \mathrm{v}$ hydrogen peroxide. The absorbance measured at $450 \mathrm{~nm}$ of each sample was recorded on a UV-visible spectrophotometer. MPO activity in the tissues was expressed as micromole per minute per milligram tissue ( $\mu \mathrm{mol} / \mathrm{min} / \mathrm{mg}$ tissue).

\section{Inducible nitric oxide synthase (iNOS) activity}

The activity of iNOS in tissues was measured spectrophotometrically as described previously. For total NOS assay, the incubation medium contained $1.6 \mu \mathrm{M}$ oxyhaemoglobin, $200 \mu \mathrm{M} \mathrm{CaCl}, 1 \mathrm{mM} \mathrm{MgCl}$, $100 \mu \mathrm{M}$ L-arginine, $100 \mu \mathrm{M}$ NADPH, $40 \mathrm{mM}$ potassium phosphate $\mathrm{pH}$ 7.2, $1 \mathrm{mM}$ NG-nitro-L-arginine, and $10 \% \mathrm{v} / \mathrm{v}$ tissue extract with $50 \mathrm{mM} \mathrm{L}$-valine to inhibit arginase [21]. For the cNOS assay, $1 \mathrm{mM}$ glycol ether diaminetetraacetic acid was added to the above incubation medium without NG-nitro-L-arginine. Oxyhaemoglobin oxidation was confirmed as being caused by NO synthesis. iNOS activity in the surrounding tissues was expressed as nanomol per minute per milligram tissue (nmol/min/mg tissue). iNOS activity was calculated by subtracting the cNOS activity from the total NOS activity.

\section{Activity of caspase proteases in the tissues surrounding the implants}

The activity of caspase enzymes was calculated by colorimetric assay. The implant surrounding tissues were homogenized with an ultraturrax homogenizer [22]. The homogenized tissues were incubated for one hour. The tissues were centrifuged and then prepared to supernatant. The supernatants were incubated with enzyme substrates. The measurements of caspase 2, 3, 8 and 9 were performed, respectively.

The released pNA was determined by the changes of absorbance at $412 \mathrm{~nm}$ using a spectrophotometer (Thermo Spectronic-HEXIOS $\beta)$. Activation percentage was calculated using the following formula: [(Absorbance/412 nm) $\times 100]$.

\section{Statistical analysis}

Data of the enzyme activities, apoptosis, and other measurement scores were subjected to one-way variance analyses (ANOVA), with the presence of negative and positive controls, using SPSS 11.0 software. Differences among the groups were attained using the Duncan option, and significance was declared at $\mathrm{P}<0.05$.

\section{Results}

\section{Evaluation of cell apoptosis by TUNEL}

Apoptotic cells in rabbits were stained with a tunnel coating (Figures 1 and 2). After the implants were placed, every group was given olive oil orally except for the healthy group. (Figure 2D) and locally (Figure $2 \mathrm{C}$ ), a significant induction was observed in the treated groups. On the contrary, the Ti-implanted group (Figure 2E) and olive oil plus Tiimplanted groups (Figure 2C and D) showed maximal apoptotic cells

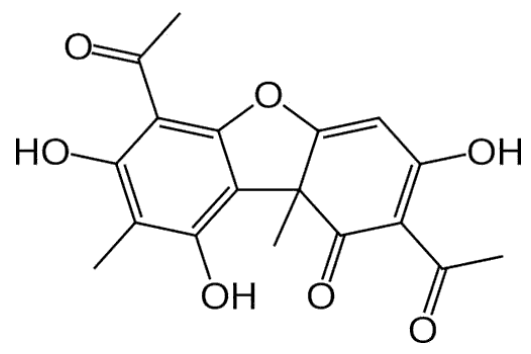

Figure 1. Structure of usnic acid
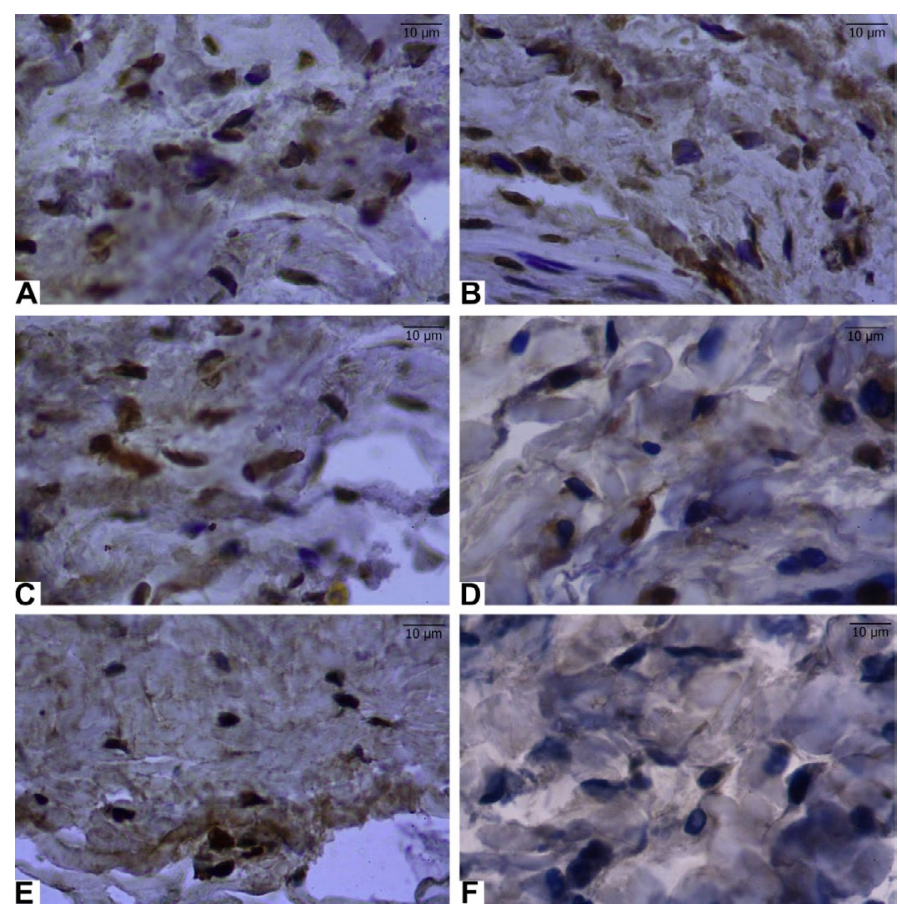

Figure 2. Apoptosis induced in the surrounding tissues of Ti-induced rabbit by both orally and locally administrated olive oil and olive oil plus usnic acid. Sections of the surrounding tissues after Ti-administration were obtained from all experimental groups. Apoptotic inflammatory cells were determined by TUNEL assay and the nucleus of TUNEL-positive cells are brown. (A): Ti-implanted and locally administrated olive oil plus usnic acid group, (B): Ti-implanted and orally administrated olive oil plus usnic acid group, (C): Ti-implanted and locally administrated olive oil group, (D); Ti-implanted and orally administrated olive oil group, (E): Only Ti-implanted group, and (F): healthy group

after both oral (Figure 2B) and local (Figure 2A) administration of olive oil plus usnic acid. Table 1 shows the summarized apoptosis results.

\section{Results of biochemical analyses}

Effects of olive oil and usnic acid on tissue activities of caspase proteases in titanium-implanted rabbits: The caspase activities in the tissues increased after implantation according to the obtained data $(\mathrm{P}<0.05)$ (Table 2 and Figure 3$)$. The most effective increase was observed in the local application of the usnic acid plus with the olive oil after implantation.

Effects of olive oil and usnic acid on the tissue activities of anti-inflammatory parameters (MPO and iNOS) in titaniumimplanted rabbits: Ti-implantation significantly reduced MPO and iNOS activity, as compared to healthy group, as well as the delivery of olive oil and usnic acid significantly $(\mathrm{P}<0.05)$ in Figure 4 and 5. The locally administered group was more effectively reduced than the orally administered group. However, combined administration of olive oil plus usnic acid to Ti-implanted rabbits reduced the iNOS and MPO activities more effectively $(\mathrm{P}<0.05)$, but not iNOS and MPO activities in the locally administrated olive oil plus usnic acid group. We also found that olive oil inhibited more effectively via local administration than oral administration. In contrast, olive oil plus usnic acid administration activated more effectively via the local route than the oral route both iNOS and MPO activities.

Effects of olive oil and usnic acid on the tissue activities of antioxidant parameters (SOD and level of GSH) in titaniumimplanted rabbits: There was a significant reduction in the implantation group according to the healthy group in GSH and SOD activity $(\mathrm{P}<0.05)$ (Figures 6 and 7$)$. Compared to the Ti implanted 
Table 1. Effects of usnic acid (UA) and olive oil (OO) on changes in quantification of the apoptotic cells by apoptotic index (AI), which was defined as the formula [(TUNEL - positive cells /counts cell number) x 100], in tissues surrounding the implants in Tiimplanted rabbits

\begin{tabular}{|c|c|c|}
\hline Treatments & $\begin{array}{c}\text { Apoptotic cell numbers } \\
\text { (dead cell number/counts } \\
\text { cell number)x100 }\end{array}$ & \% Activation $^{\mathbf{b}}$ \\
\hline Ti+OO+UA (local) & $102.1 \pm 10.2 \mathrm{e}$ & 283.6 \\
\hline Ti+OO+UA (orally) & $73.0 \pm 0.6 \mathrm{~d}$ & 202.8 \\
\hline Ti+OO (local) & $63.3 \pm 0.6 \mathrm{c}, \mathrm{d}$ & 175.8 \\
\hline Ti+OO (orally) & $52.0 \pm 0.6 \mathrm{c}$ & 144.4 \\
\hline Titanium (Control) & $36.0 \pm 0.8 \mathrm{~b}$ & 100 \\
\hline Healthy & $9.8 \pm 0.4 \mathrm{a}$ & - \\
\hline
\end{tabular}

Usnic acid, UA; olive oil, OO; apoptotic index (AI); titanium, Ti; Means in the same column by the same letter are not significantly different to the Duncan test $(=0.05)$. a Mean $\mathrm{AI} \pm \mathrm{SE}$ of six legs in each group. b\% Inhibition $\mathrm{In} \mathrm{AI}$ in relation to Ti-implanted group.

Table 2. Effects of olive oil (OO) and usnic acid (UA) on changes in the activity of caspase proteases (caspase-2, $-3,-8$ and -9) in tissues surrounding implant of titanium (Ti)implanted rabbits

\begin{tabular}{|c|c|c|c|c|}
\hline Treatments & $\begin{array}{c}\text { Caspase-2 } \\
\text { activity }\end{array}$ & $\begin{array}{c}\text { Caspase-3 } \\
\text { activity }\end{array}$ & $\begin{array}{c}\text { Caspase-8 } \\
\text { activity }\end{array}$ & $\begin{array}{c}\text { Caspase-9 } \\
\text { activity }\end{array}$ \\
\hline $\begin{array}{c}\text { Ti+OO+UA } \\
\text { (locally) }\end{array}$ & $160.0 \pm 1.3 \mathrm{~d}$ & $367.2 \pm 5.4 \mathrm{f}$ & $268.8 \pm 1.2 \mathrm{f}$ & $359.8 \pm 1.1 \mathrm{f}$ \\
\hline $\begin{array}{c}\text { Ti+ OO+UA } \\
\text { (orally) }\end{array}$ & $146.8 \pm 0.9 \mathrm{c}$ & $232.3 \pm 2.0 \mathrm{e}$ & $210.6 \pm 1.4 \mathrm{e}$ & $287.9 \pm 1.0 \mathrm{e}$ \\
\hline $\mathbf{T i}+\mathbf{O O}$ (locally) & $159.8 \pm 1.0 \mathrm{~d}$ & $190.7 \pm 1.0 \mathrm{~d}$ & $193.0 \pm 0.4 \mathrm{~d}$ & $227.3 \pm 1.2 \mathrm{~d}$ \\
\hline $\mathbf{T i + O O}$ (orally) & $146.2 \pm 0.8 \mathrm{c}$ & $177.3 \pm 0.6 \mathrm{c}$ & $162.0 \pm 1.1 \mathrm{c}$ & $212.8 \pm 1.0 \mathrm{c}$ \\
\hline $\begin{array}{c}\text { Titanium } \\
\text { (Control) }\end{array}$ & $104.2 \pm 2.5 \mathrm{~b}$ & $113.0 \pm 0.8 \mathrm{~b}$ & $114.9 \pm 0.7 \mathrm{~b}$ & $125.1 \pm 0.5 \mathrm{~b}$ \\
\hline Healthy & $42.1 \pm 0.8 \mathrm{a}$ & $33.5 \pm 0.8 \mathrm{a}$ & $26.5 \pm 0.4 \mathrm{a}$ & $23.7 \pm 0.5 \mathrm{a}$ \\
\hline
\end{tabular}

Means in the same column by the same letter are not significantly different to the Duncan test $(=0.05)$. Results are means $\pm \mathrm{SE}$ of three measurements [caspase avtivity $=$ (Absorbance/412nm) x100].

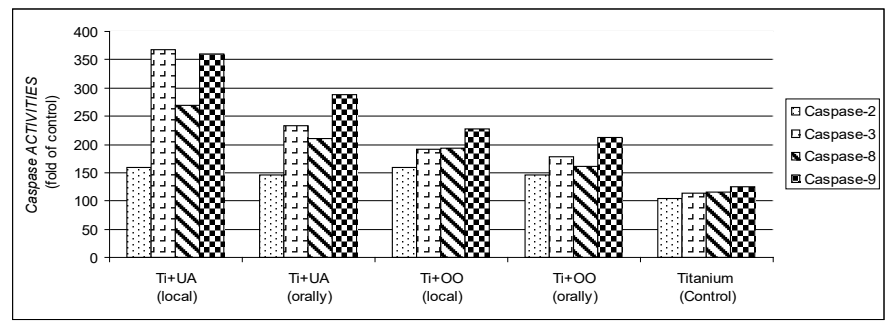

Figure 3. Effects of olive oil (OO) and usnic acid (UA) on changes in the activity of caspase proteases (caspase-2, $-3,-8$ and -9 ), in tissues surrounding implant of titanium (Ti)implanted rabbits. The data were represented by fold of control

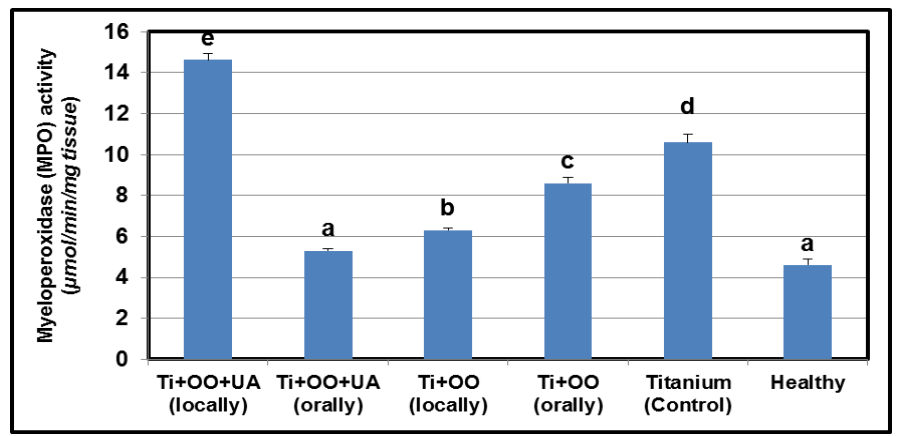

Figure 4. Effects of usnic acid (UA) and olive oil (OO) on changes in the activity of myeloperoxidase (MPO) in tissues surrounding implant of titanium (Ti)-implanted rabbits, in tissues surrounding implant of titanium (Ti)-implanted rabbits. Means in the same column by the same letter are not significantly different to the Duncan test $(=0.05)$. Results are means $\pm \mathrm{SE}$ of three measurements

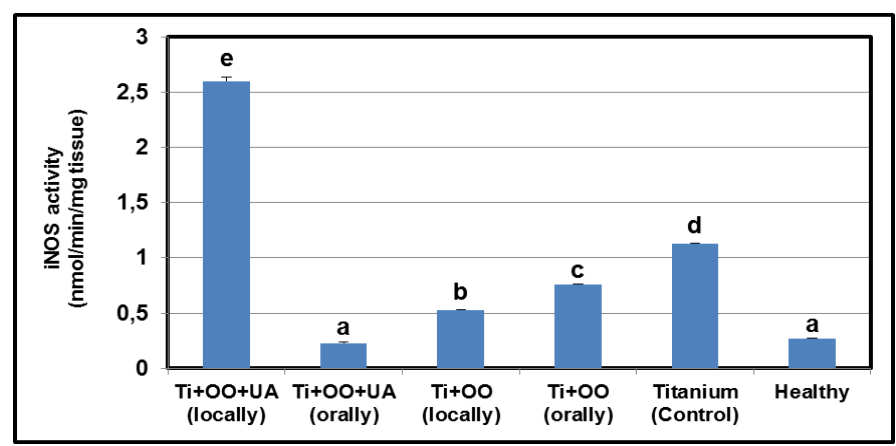

Figure 5. Effects of usnic acid (UA) and olive oil (OO) on changes in the activity of inducible nitric oxide synthase (iNOS) in tissues surrounding implant of titanium (Ti)implanted rabbits, in tissues surrounding implant of titanium (Ti)-implanted rabbits. Means in the same column by the same letter are not significantly different to the Duncan test $(=0.05)$. Results are means $\pm \mathrm{SE}$ of three measurements

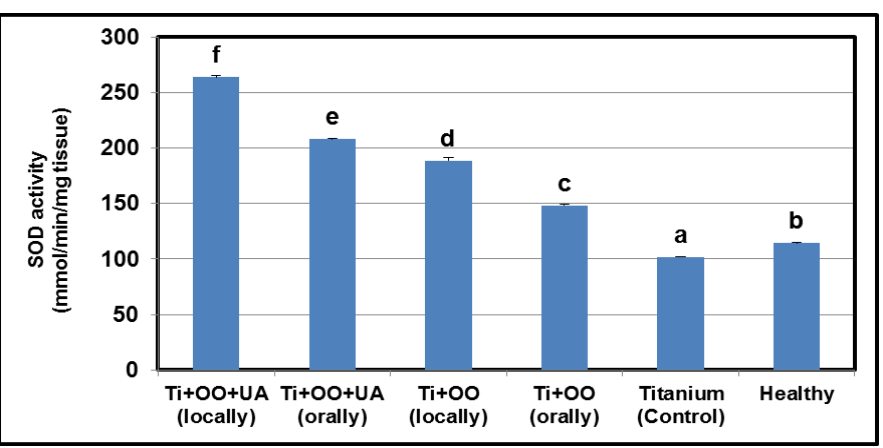

Figure 6. Effects of usnic acid (UA) and olive oil (OO) on changes in the activity of superoxide dismutase (SOD) in tissues surrounding implant of titanium (Ti)-implanted rabbits, in tissues surrounding implant of titanium (Ti)-implanted rabbits. Means in the same column by the same letter are not significantly different to the Duncan test $(=0.05)$. Results are means $\pm \mathrm{SE}$ of three measurements

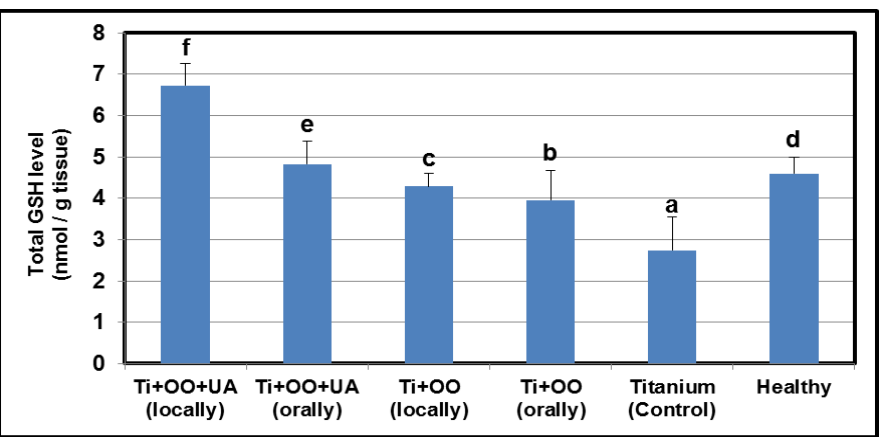

Figure 7. Effects of usnic acid (UA) and olive oil (OO) on changes in the total glutathione (GSH) level in tissues surrounding implant of titanium (Ti)-implanted rabbits, in tissues surrounding implant of titanium (Ti)-implanted rabbits. Means in the same column by the same letter are not significantly different to the Duncan test $(=0.05)$. Results are means \pm SE of three measurements

group, the SOD activity and GSH level were found to have increased in olive oil and olive oil plus usnic acid administered groups $(\mathrm{P}<0.05)$. Local administrations of olive oil and olive oil plus usnic acid were more effective than oral administrations in increasing the SOD activity and GSH level. When we evaluated the overall results, we identified that the most effective treatments for increasing SOD activity and GSH level (Figures 6 and 7) were local administrations of olive oil plus usnic acid, on the other hand, local administrations of olive oil plus usnic acid have an effect to increase the activities of MPO and iNOS. 


\section{Discussion}

In post inflammation period, Titanium alloy initiate the inflammation process. Process is terminated by tissue damage, organ dysfunctions and apoptosis. However, the apoptosis mechanism of surrounding tissues could not be explained. This mechanism has similar feature with the tissue which contain titanium alloy implantation. In former studies, it is observed that apoptosis occurred in surrounding tissues was familiar with osteoblast. In present study, Both oral and local simultaneous administration of OO and UA increased apoptosis in surrounding tissues [3]. It is reported in literature that olive oil and some lichen species have pro-apoptotic feature. According to our observed data, it could be claimed that $\mathrm{OO}$ and UA may have play significant role in surrounding tissues of peri-implanted rabbits [23,24]. It is thought that apoptosis initiated by natural compounds may have protective effect on several cancer species [25].

Activation of caspase enzymes is very important in apoptotic process [15]. This enzyme is activated via sensors of apoptotic pathways in order to initiate caspase cascade. Executioner caspases have two different ways to physiological process of apoptosis. After activating, the caspase cascade can be started. Executioners are activated in two ways in apoptosis. They are stimulated by death receptors in the first path (FAS, CD95, TNF family, APO 1.vs). The activated receptors also include adapter proteins and caspases that activate caspase cascade [3]. They are stimulated by interacting with various events such as p53, Bax, sitocrom c, JNK, Bid, NO• and ONOO• [26].

In this study, caspase 2, 3, 8 and 9 was activated in surrounding tissues of ti-implanted rabbits. It is determined that simultaneous administration of $\mathrm{OO}$ and UA significantly increase that activation in both local and oral applications. According to these results, it could be claimed that UA and OO have pro-apoptotic feature.

It is indicated that $\mathrm{Ti}$ implant induced apoptosis via caspase enzyme activation [27]. By the way, lichen metabolites was also induced mitochondrial apoptosis in accordance with several studies in literature $[15,28]$. However, there is not sufficient data about this issue. Limited information take part in literature about secondary metabolites of lichen species $[23,29]$. Several works was published for the effects of lichen metabolites on human melanoma cells, L1210-treated cells, A2780 and HT-29 cancer cell lines rat hepatocytes, prostate cancer cells, human lung carcinoma A549 cells, human colon carcinoma LS174 cells and melanoma FemX cells, the breast cancer cell line T-47D and the pancreatic cancer cell line Capan-2. (36) Obtained results compatible with recent studies [27,30-36].

In this study it is aimed to exhibit the effects of INOS, MPO and SOD enzymes, GSH levels on activation of apoptosis and caspase enzyme. NO generation via iNOS enzyme is one of the most important stimulants of apoptosis [14]. Nitric oxide (NO•) can contribute in apoptosis and caspase activation in four ways:

(1) The NO• level is increased when TNF- $\alpha$ is stimulated [15] .

The level of increased nitric oxide inhibits formation of JNK. Apoptosis can be increased by stimulating caspase 9, TNF- $\alpha$, JNK and Bax when there is a decrease in iNOS activity $[37,38]$

(2) Increasing the level of NO may decrease apoptosis by inhibiting the caspase; [39]

(3) Increased nitric oxide penetrates into the nucleus. The p53 gene activates with a catalytic reaction. The activated gene both opens Bax $\rightarrow$ cytochrome $c \rightarrow$ caspase 9 way and activates CD95 and PIDD (RAIDD); [40]
(4) Increased NO• can reduce apoptosis via preventing cytochrome c and apoptosom formation by cytosolic head shock proteins (HSP, -70 and -90$)$ [41].

In the current study, it was determined that oral administration inhibited inos more significantly than local administration. Therefore, this inhibition could be caused by four different mechanism mentioned above.

This means that usnic acid and olive oil might have been stimulated the JNK $\rightarrow$ Bax $\rightarrow$ cytochrome $c \rightarrow$ caspase 9 pathway with the TNF- $\alpha$ induction that increase iNOS-induced NO•, and at the end caspase 9 was activated. The results are consistent with the literature and support that apoptosis is an important regulator [15,37].

In other words, iNOS activity significantly increase in several tissues contain either Ti implant or apoptosis. In recent studies, it is monitored that iNOS activity may decrease due to olive oil and some lichen species [15]. MPO enzymes generate $\cdot \mathrm{NO}_{2}$ from $\mathrm{H}_{2} \mathrm{O}_{2}$ and $\mathrm{NO}_{2}$. Production of $\mathrm{NO}_{2}$ was provided by JNK promotion, $\mathrm{P} 53$ gene stimulation and caspase 9 activation [15]. In present study, MPO activity is significantly decreased by oral administration of OO and UA. These results showed that $\mathrm{NO}_{2}$ may be produced under these circumstances. Both conditions increase apoptosis. Thus, UA and OO participate in NO production via iNOS and activation of Caspase 2, 8 and 9 via MPO. The activation of these enzymes promote synthesis of caspase 3,6 and 7 [42]. In some studies, it is exhibited that MPO activity decreased by oral administration of $\mathrm{OO}$ and some lichen species.

Decrease in SOD activity and GSH level cause not only cumulation of superoxide and other oxygen radicals but also cell damage $[37,43]$. This circumstance is related with mitochondrial apoptosis. Increase of $\mathrm{H} 2 \mathrm{O} 2$ in mitochondria plays an important role along apoptotic process [15]. Increase in $\mathrm{H}_{2} \mathrm{O}_{2}$ level stimulate secretion of Cytochrome $\mathrm{C}$ from mitochondria to cytoplasm. Cit C promotes caspase 9 and APAF 1 that is responsible for production reaction of activated caspase 3 from procaspase 3. Then, Caspase 3 induces caspase 6 and 7 in order to apoptozis $[15,37]$. The results of the experiment can support this hypothesis. The decrease in both SOD activity and GSH level could be caused in effect of the permanent Ti implantation-induced oxidative stress. In the current work, SOD activity and GSH levels are reported that increased by usnic acid and olive oil. An increase in $\mathrm{H} 2 \mathrm{O} 2$ with a simultaneous increase in SOD activity causes to increased mitochondrial cytochrome $c$ release and the induction of apoptosis through the activation of caspase 9. Previous studies have shown that non-sized titanium dioxide reduces SOD activity under different conditions $[44,45]$. Some studies have reported that GSH consumption may be due to apoptosis and tissue damage [15]. It was determined that oral administration olive oil and some lichen species increased both SOD activity and GSH levels in some diseases $[9,14,15]$. These findings are parallel to the present study. The current study is the first findings of titanium-induced rabbits. The proapoptotic effect of olive oil and usnic acid was demonstrated.The apoptosis plays an important role in homeostasis in multicellular organisms. The disruption of the process can be devastating in apoptosis because the cell number is regulated in the embryo. unspecified apoptosis may result from many different conditions such as diabetes, systemic lupus erythematosus, cancer, mononucleosis, AIDS, Alzheimer's disease, confirmed hepatitis, Parkinson's disease and cerebral or cardiac infarction. In addition, the results of the study indicate that it can be used as an agent in disorders related to cancer. However, it is not tried in other cancer models, usnic acid belongs to a detailed research. In conclusion, we have demonstrated that both orally and locally administered olive oil 
and usnic acid exerted pro-apoptotic effects on surrounding tissues of titanium-implanted rabbits. As a result, the proapoptotic effects of usnic acid and olive oil, which are applied both orally and orally, have been demonstrated. therefore, we can be used as an agent in the treatment of various diseases.

\section{Acknowledgments}

This research was conducted in the Laboratory of Biochemistry and Pharmacology of Faculty of Pharmacy, Laboratories of PharmacologyPathology-Histology-Embryology of Medical Faculty, and Laboratories of Experimental Medical Application and Research Center, at Ataturk University, 25240 Erzurum/Turkey.

We thank Dr. Halis Suleyman for his excellent technical support, and Dr. Cavit Kazaz for his precious help with the molecular characterization. We also thank Ataturk University Scientific Research Unit for their kind project supports.

\section{Author Contributions}

F.O. and O.S.Y. carried out project planning, experimental design, experimental work and data analysis. O.S.Y., and H.A. carried out experiments for implantation operations. F.A., O.A.B., M.H., Y.B. and A.C. carried out experiments for isolation, characterization, and biochemical assays and data analysis. A.A. performed plant collection and systematics studies. B.A. performed all implant procedures. F.E and I.C carried out experiments for histology and histo-pathological analysis. Z.H. and E.C. carried out experiments for pharmacological experiments. F.O. supervised the study, committed to writing the correspondence of the manuscript, and wrote the paper with F.A. and O.A.

\section{Conflict of interest}

Authors have no commercial interest, financial interest, and/ or other relationship with the manufacturers of pharmaceuticals, laboratory supplies, and/or medical devices or with commercial providers of medically related services.

\section{References}

1. Cunningham BW, Orbegoso CM, Dmitriev AE, Hallab NJ, Sefter JC, et al. (2002) The effect of titanium particulate on development and maintenance of a posterolateral spinal arthrodesis: an in vivo rabbit model. Spine 27: 1971-1981. [Crossref]

2. Pioletti DP, Takei H, Kwon SY, Wood D, Sung KL (1993) The cytotoxic effect of titanium particles phagocytosed by osteoblasts. J Biomed Mater Res 46: 399-407.

3. Krug HF (2002) Metals in clinical medicine: the induction of apoptosis by metal compounds. Materialwissenschaft Und Werkstofftechnik 33: 770-774.

4. Zheng TS, Hunot S, Kuida K, Flavell RA (1999) Caspase knockouts: matters of life and death. Cell Death Differ 6: 1043-1053. [Crossref]

5. Halliwell B, Gutteridge JMC (1999) Free radicals, other reactive species and disease. In: Free Radicals in Biology and Medicine. (3rd edn) Oxford University Press, New York.

6. Atalay F, Odabasoglu F, Halici M, Cadirci E, Aydin O, et al. (2016) N-Acetyl Cysteine Has Both Gastro-Protective and Anti-Inflammatory Effects in Experimental Rat Models: Its Gastro-Protective Effect Is Related to Its In Vivo and In Vitro Antioxidant Properties. J Cell Biochem 117: 308-319. [Crossref]

7. Demir L, Togar B, Turkez H, Sozio P, Aslan A, et al. (2015) The Investigation of Cytogenetic and Oxidative Effects of Diffractaic Acid on Human Lymphocyte Cultures. Braz Arch Biol Technol 58: 75-81.

8. Halici M, Odabasoglu F, Suleyman H, Cakir A, Aslan A, et al. (2005) Effects of water extract of Usnea longissima on antioxidant enzyme activity and mucosal damage caused by indomethacin in rats. Phytomedicine 12: 656-662. [Crossref]
9. Polat B, Albayrak Y, Suleyman B, Dursun H, Odabasoglu F, et al. (2016) Antiulcerative effect of dexmedetomidine on indomethacin-induced gastric ulcer in rats. Pharmacol Rep 63: 518-526. [Crossref]

10. Behera BC, Mahadik N, Morey M (2012) Antioxidative and cardiovascular-protective activities of metabolite usnic acid and psoromic acid produced by lichen species Usnea complanata under submerged fermentation. Pharm Biol 50: 968-979. [Crossref]

11. Backorova M, Backor M, Mikes J, Jendzelovsky R, Fedorocko P (2011) Variable responses of different human cancer cells to the lichen compounds parietin, atranorin, usnic acid and gyrophoric acid. Toxicol In Vitro. $25: 37-44$. [Crossref]

12. Brisdelli F, Perilli M, Sellitri D, Piovano M, Garbarino JA, et al. (2013) Cytotoxic activity and antioxidant capacity of purified lichen metabolites: an in vitro study. Phytother Res 27: 431-437. [Crossref]

13. White PA, Oliveira RC, Oliveira AP, Serafini MR, Araujo AA, et al. (2014) Antioxidant activity and mechanisms of action of natural compounds isolated from lichens: a systematic review. Molecules 19: 14496-14527. [Crossref]

14. Odabasoglu F, Halici Z, Cakir A, Halici M, Aygun H, et al. (2008) Beneficial effects of vegetable oils (corn, olive and sunflower oils) and alpha-tocopherol on antiinflammatory and gastrointestinal profiles of indomethacin in rats. Eur J Pharmacol 591: 300-306. [Crossref]

15. Odabasoglu F, Yildirim OS, Aygun H, Halici Z, Halici M, et al. (2012) Diffractaic acid, a novel proapoptotic agent, induces with olive oil both apoptosis and antioxidative systems in Ti-implanted rabbits. Eur J Pharmacol 674: 171-178. [Crossref]

16. Huneck S, Yoshimura I (1996) Identification of Lichen Substances. Springer, Verlag, Berlin.

17. Care CCoA (1993) Guide to the care and use of experimental animals. (2nd edn) Bradda Printing Services Inc, Ottawa, ON, Canada.

18. Sun Y, Oberley LW, Li Y (1988) A Simple Method for Clinical Assay of SuperoxideDismutase. Clinical Chemistry 34: 497-500. [Crossref]

19. Sedlak J, Lindsay RH (1968) Estimation of total, protein-bound, and nonprotein sulfhydryl groups in tissue with Ellman's reagent. Anal Biochem 25: 192-205. [Crossref]

20. Bradley PP, Priebat DA, Christensen RD, Rothstein G (1982) Measurement of cutaneous inflammation: estimation of neutrophil content with an enzyme marker. $J$ Invest Dermatol 78: 206-209.

21. Knowles RG, Salter M, Brooks SL, Moncada S (1990) Anti-inflammatory glucocorticoids inhibit the induction by endotoxin of nitric oxide synthase in the lung, liver and aorta of the rat. Biochem Biophys Res Commun 172: 1042-1048.

22. Osawa Y, Banno Y, Nagaki M, Nozawa Y, Moriwaki H, Nakashima S (2001) Caspase activation during hepatocyte apoptosis induced by tumor necrosis factor-alpha in galactosamine-sensitized mice. Liver 21: 309-319. [Crossref]

23. Ren MR, Hur JS, Kim JY, Park KW, Park SC, et al. (2009) Anti-proliferative effects of Lethariella zahlbruckneri extracts in human HT-29 human colon cancer cells. Food Chem Toxicol 47: 2157-2162. [Crossref]

24. Srinivas G, Babykutty S, Sathiadevan PP, Srinivas P (2007) Molecular mechanism of emodin action: transition from laxative ingredient to an antitumor agent. Med Res Rev 27: 591-608. [Crossref]

25. Kerr JF, Winterford CM, Harmon BV (1994) Apoptosis: Its significance in cancer and cancer therapy. Cancer 73: 2013-2026. [Crossref]

26. Kalmar B, Greensmith L (2009) Induction of heat shock proteins for protection against oxidative stress. Advanced Drug Delivery Reviews 61: 310-318. [Crossref]

27. Backorova M, Jendzelovsky R, Kello M, Backor M, Mikes J, Fedorocko P (2012) Lichen secondary metabolites are responsible for induction of apoptosis in HT-29 and A2780 human cancer cell lines. Toxicol In Vitro 26: 462-468.

28. Fabiani R, De Bartolomeo A, Rosignoli P, Servili M, Selvaggini R, Montedoro GF, et al (2006) Virgin olive oil phenols inhibit proliferation of human promyelocytic leukemia cells (HL60) by inducing apoptosis and differentiation. J Nutr 136: 614-619. [Crossref]

29. Bezivin C, Tomasi S, Lohezic-Le Devehat F, Boustie J (2003) Cytotoxic activity of some lichen extracts on murine and human cancer cell lines. Phytomedicine 10: 499503. [Crossref]

30. Russo A, Piovano M, Lombardo L, Garbarino J, Cardile V (2008) Lichen metabolites prevent UV light and nitric oxide-mediated plasmid DNA damage and induce apoptosis in human melanoma cells. Life Sci 83: 468-474.

31. Bazin MA, Le Lamer AC, Delcros JG, Rouaud I, Uriac P, Boustie J, et al. (2008) Synthesis and cytotoxic activities of usnic acid derivatives. Bioorg Med Chem 16: 6860-6866. [Crossref] 
32. Correche ER, Enriz RD, Piovano M, Garbarino J, Gomez-Lechon MJ (2004) Cytotoxic and apoptotic effects on hepatocytes of secondary metabolites obtained from lichens. Altern Lab Anim 32: 605-615. [Crossref]

33. Russo A, Caggia S, Piovano M, Garbarino J, Cardile V (2012) Effect of vicanicin and protolichesterinic acid on human prostate cancer cells: role of Hsp70 protein. Chem Biol Interact 195: 1-10. [Crossref]

34. Singh N, Nambiar D, Kale RK, Singh RP (2013) Usnic acid inhibits growth and induces cell cycle arrest and apoptosis in human lung carcinoma A549 cells. Nutr Cancer 65: 36-43. [Crossref]

35. Ranković B, Kosanić M, Stanojković T, Vasiljević P and Manojlović N (2012) Biological activities of Toninia candida and Usnea barbata together with their norstictic acid and usnic acid constituents. Int J Mol Sci 13: 14707-14722.

36. Einarsdottir E, Groeneweg J, Bjornsdottir GG, Harethardottir G, Omarsdottir S, et al (2010) Cellular mechanisms of the anticancer effects of the lichen compound usnic acid. Planta Med 76: 969-974.

37. Circu ML, Aw TY (2010) Reactive oxygen species, cellular redox systems, and apoptosis. Free Radic Biol Med 48: 749-762. [Crossref]

38. Park HS, Huh SH, Kim MS, Lee SH, Choi EJ (2000) Nitric oxide negatively regulates c-Jun N-terminal kinase/stress-activated protein kinase by means of S-nitrosylation. Proc Natl Acad Sci USA 97: 14382-14387. [Crossref]
39. Brune B (2003) Nitric oxide: NO apoptosis or turning it ON? Cell Death Differ. 10: 864-869. [Crossref]

40. Murphy MP (1999) Nitric oxide and cell death. Biochim Biophys Acta 1411: 401-414 [Crossref]

41. Blaise GA, Gauvin D, Gangal M, Authier S (2005) Nitric oxide, cell signaling and cell death. Toxicology 208: 177-192.

42. Singh S, Dikshit M (2007) Apoptotic neuronal death in Parkinson's disease: involvement of nitric oxide. Brain Res Rev 54: 233-250.

43. Afaq F, Abidi P, Matin R, Rahman Q (1998) Cytotoxicity, pro-oxidant effects and antioxidant depletion in rat lung alveolar macrophages exposed to ultrafine titanium dioxide. J Appl Toxicol 18: 307-312. [Crossref]

44. Ma L, Ze Y, Liu J, Liu H, Liu C, Li Z, et al. (2009) Direct evidence for interaction between nano-anatase and superoxide dismutase from rat erythrocytes. Spectrochim Acta A Mol Biomol Spectrosc 73: 330-335. [Crossref]

45. Odabasoglu F, Halici Z, Aygun H, Halici M, Atalay F, et al. (2011) Alpha-Lipoic acid has anti-inflammatory and anti-oxidative properties: an experimental study in rats with carrageenan-induced acute and cotton pellet-induced chronic inflammations. Brit $J$ Nutr 105: 31-43.

Copyright: (C2019 Odabasoglu F. This is an open-access article distributed under the terms of the Creative Commons Attribution License, which permits unrestricted use, distribution, and reproduction in any medium, provided the original author and source are credited. 